\title{
IDENTIFIKASI KUPU-KUPU RHOPALOCERA DAN VEGETASI HABITAT BERDASARKAN KARAKTER MORFOLOGI PADA BEBERAPA KAWASAN RESORT TALANG LAKAT TAMAN NASIONAL BUKIT TIGA PULUH PROVINSI RIAU
}

\author{
Identification of Rhopalocera butterflies and habitat vegetation based on \\ morphological characters in several Talang Lakat Resort Area Bukit Tiga Puluh \\ National Park, Riau Province \\ Ennie Chahyadi $^{a *}$, Appriliya Destiyana $^{a}$, Mayta Novaliza Isda $^{a}$, Desita Salbiah $^{b}$ \\ a Jurusan Biologi, FMIPA, Universitas Riau, Jl. Bina Widya Simpang Baru, Pekanbaru \\ Riau 28293 telp/fax (0761) 63273/63279 \\ ${ }^{b}$ Jurusan Agroteknologi, FAPERTA, Universitas Riau, Jl. Bina Widya Simpang Baru, \\ Pekanbaru Riau 28293 telp/fax (0761) 63270/63271 \\ *email: ennie.chahyadi@gmail.com
}

\begin{abstract}
Bukit Tiga Puluh National Park (TNBT) is a nature conservation area that has a variety of important and interesting fauna, one of which is a butterfly. The existence of butterflies in an ecosystem acts as a bioindicator, pollinator, and high aesthetic value. The type and number of butterflies are influenced by various environmental factors, one of the most important factors is the types of plants as vegetation habitat. The existence of different habitat conditions can be found in several areas in the Talang Lakat Resort TNBT Utilization Zone, namely in the area of Mu'un Lake and Camp Granite. The study was to identify and inventory the Rhopalocera butterfly based on morphological characters and the presence of differences in habitat vegetation in the two areas in the TNBT utilization zone. The method used is the method of roaming with the help of insect nets. Sampling was carried out starting from the morning (08.00-11.00 WIB) until the afternoon (15.0017.30 WIB). Samples obtained immediately made insectarium and identified. The results obtained are that there are some different types of butterflies and plants between the Granite Camp region (15 and 26 species) and mu'un lake (7 and 15 species). The butterflies obtained consisted of the Hesperiidae, Lycaenidae, Papilionidae, Nympalidae and Pieridae families. The highest number of species and individuals of butterflies in the two regions comes from the Nympalidae Family. The differences in the types of butterflies in the two regions are influenced by the quite high differences in the number of plant species that dominate in each region which is a habitat for butterflies. Besides physical factors also support the existence of butterflies (temperature, light intensity, humidity)
\end{abstract}

Keywords: Morphological Character, Rhopalocera, TNBT, Plant Vegetation

\section{PENDAHULUAN}

Taman Nasional Bukit Tiga Puluh (TNBT) adalah salah satu Kawasan Pelestarian Alam (KPA) yang penting di Provinsi Riau Sumatera bagian tengah. Kawasan TNBT terletak di Kabupaten Indragiri Hulu dan Hilir Provinsi Riau, serta Kabupaten Tanjung 
Jabung Barat dan Kabupaten Tebo Provinsi Jambi. KPA tersebut memiliki tipe ekosistem hutan tropis dataran rendah yang dibagi dalam tiga zona utama berdasarkan zonasi indikatif, yaitu zona inti, zona rimba dan zona pemanfaatan (BTNBT 2014). Pada zona pemanfaatan terdapat danau dan bukit yang memiliki perbedaan tipe habitat berupa vegetasi dan sumber air (BTNBT 2014) yang tentu saja hal ini dapat mempengaruhi keberagaman fauna yang ada di dalamnya salah satunya yaitu kupu-kupu (Sulistyani 2013).

Kupu-kupu termasuk ke dalam Ordo Lepidoptera Subordo Rhopalocera. Ciri khas serangga ini memiliki sayap yang bersisik indah. Corak dan pola warna kupu-kupu sangat menarik (Scoble 1995; Campbel et al. 2000), sehingga mampu menjadi pesona suatu kawasan dan objek wisata. Peran kupu-kupu di dalam ekosistem juga tidak kalah penting yaitu sebagai polinator dan bioindikator yang mampu ikut memelihara keanekaragaman hayati (Rizal 2007; Subahar \& Yuliana 2012; Peggie 2014).

Keberadaan jenis kupu-kupu dipengaruhi oleh vegetasi di habitatnya (Rinanda et al. 2016). Terdapat beberapa faktor lingkungan yang mempengaruhi keberagaman jenis kupu-kupu diantaranya jenis tanaman, suhu udara dan pencahayaan (Putri 2014). Pentingnya inventarisasi dapat digunakan sebagai langkah awal untuk konservasi dan pengelolaan kupu-kupu di wilayah TNBT dengan diseimbangkan pada kondisi habitat yang ada. Namun belum diketahui jenis kupu-kupu di Lokasi Resort Talang Langkat Zona Pemanfaat TNBT, oleh karena itu menarik untuk melakukan inventarisasi jenis kupu-kupu di kawasan tersebut. Penelitian ini bertujuan untuk mengidentifikasi dan menginventarisasi kupu-kupu Rhopalocera berdasarkan karakter morfologi dan adanya perbedaan vegetasi habitat pada dua kawasan di zona pemanfaatan TNBT Provinsi Riau.

\section{METODE}

Penelitian dilakukan pada bulan April 2019. Sampel kupu-kupu diambil di kawasan konservasi Resort Talang Lakat, Zona Pemanfaatan TNBT Provinsi Riau yaitu wilayah danau Mu'un (S 0050'28.6' E 102³0'59.8'') dan Camp Granit (S 0050'09.4' E $\left.102^{\circ} 31^{\prime} 18.6^{\prime \prime}\right)$. Identifikasi kupu-kupu dan analisis data dilakukan di Laboratorium Zoologi, FMIPA Universitas Riau. Pembagian wilayah sampel didasarkan pada kondisi vegetasi yang ada pada tiap wilayah. Danau Mu'un didominasi komposisi vegetasi yaitu pepohonan dan semak serta sumber air yaitu danau. Camp Granit dengan kondisi vegetasi rerumputan dan intensitas cahaya tinggi karna tipe lahan terbuka (BTNBT 2014). Perbedaan habitat tiap wilayah diperkirakan akan mempengaruhi keanekaragaman spesies kupu-kupu dan faktor lingkungan seperti suhu, intensitas cahaya dan kelembapan.

Observasi dan Koleksi. Observasi kupu-kupu dilakukan pada hari cerah yaitu pukul 08.00-11.30 WIB dan 15.00-17.30 WIB. Setiap wilayah penangkapan kupu-kupu dilakukan tiga kali pengamatan sehingga total pengambilan sampel yaitu selama 6 hari. Rute jelajah untuk tiap wilayah sejauh 1,5 km sambil melakukan penangkapan kupu-kupu dengan jaring seranga (Insect net). Sampel kupu-kupu yang berukuran kecil dimatikan dengan cara menekan bagian toraksnya dan kupu-kupu berukuran sedang-besar dibius dengan alkohol $70 \%$ pada bagian dada. Kemudian, kupu-kupu dimasukkan ke dalam amplop papilot dengan keadaan kedua sayap ditangkupkan agar tidak rusak (Arisandi \& Syamsi 2018). Pengambilan sampel dibatasi dengan tiga individu tiap spesiesnya. Pengukuran faktor fisika dilakukan dengan mengukur suhu menggunakan thermometer kaca ZEAST, kelembapan menggunakan Hygrometer Fischer dan intensitas cahaya luxmeter LX-101AS. Pengukuran dilakukan setiap hari di tiap wilayah. Sampel tumbuhan yang dikunjungi oleh kupu-kupu diambil menggunakan gunting tanaman dan dicatat informasi penting dalam etiket. 
Preparasi dan identifikasi. Sampel kupu-kupu yang didapatkan kemudian di pinning dengan menusukkan jarum pada bagian dada dan merentangkan sayap kupu-kupu di atas papan perentang. Sayap kupu-kupu ditutupi dengan kertas minyak mencegah kerusakan pada sayap. Sampel kupu-kupu kemudian dikeringkan dengan oven selama dua hari atau disesuaikan dengan ukuran tubuh kupu-kupu. Kupu-kupu yang kering kemudian diatur dalam kotak penyimpanan (Herlina 2017). Identifikasi kupu-kupu merujuk pada buku Borror (1992), Corbet \& pendlebury (1992), Braby 2004, Triplehorn \& Johnson 2005 dan Peggie dan Amir (2006). Pada karakter warna merujuk karakter warna munsell. Proses identifikasi kupu-kupu berdasarkan karakter morfologi yang disajikan pada Gambar 1. Pengukuran kupu-kupu menggunakan software ImageJ (Rueden et al. 2017). Semua sampel kupu-kupu dilakukan pengambilan gambar untuk analisis data menggunakan kamera Canon 1300D. Sampel tumbuhan yang di dapatkan kemudian dilakukan teknik herbarium: sampel disusun ke dalam kertas koran kemudian diberi alkohol $70 \%$. Sampel dikeringkan dengan cara dioven sekitar sekitar lima hari dengan suhu $60^{\circ} \mathrm{C}$. Setelah kering sampel ditata rapi di atas kertas dan kemudian diberi voucher specimen. Tumbuhan selanjutnya diidentifikasi berdasarkan karakter akar, batang dan daun menggunakan Plant of Southeast Asia, Flora cagar alam gunung tikung gede serang banten (Djarwaningsi et al. 2011), The Plant List (2013).

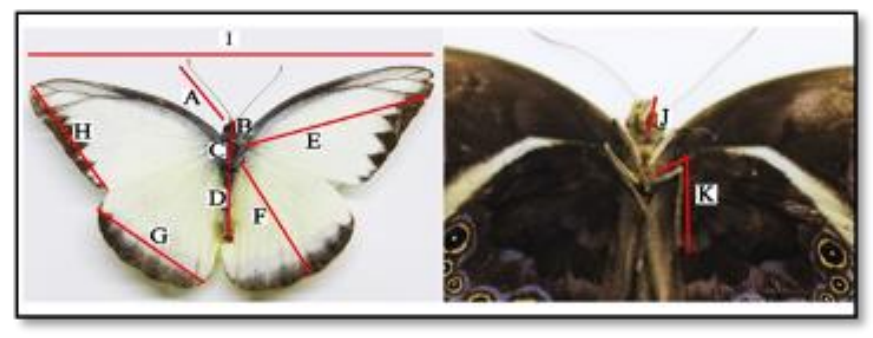

Gambar 1. Bagian tubuh kupu-kupu yang dikukur untuk identifikasi. A: Panjang antena, B: Panjang kepala, C: Panjang dada, D: Panjang perut, E: Panjang sayap atas, F: Panjang sayap bawah, G: Lebar sayap bawah, H: Lebar sayap atas, I: Panjang rentang sayap, J: Panjang labial pulp, K: Panjang tungkai.

\section{HASIL DAN PEMBAHASAN}

\section{Jumlah individu dan spesies dari beberapa famili kupu-kupu}

Berdasarkan hasil penelitian, kupu-kupu yang didapatkan terdiri dari 22 spesies dari lima famili. Famili kupu-kupu yang berhasil ditangkap yaitu famili Hesperiidae satu spesies, Lycaenidae satu spesies, Papilionidae empat spesies, Nymphalidae 12 spesies dan Pieridae empat spesies. Total kupu-kupu yang tercatat pada dua wilayah yaitu danau Mu'un dan Camp Granit sebanyak 32 individu (Tabel 1).

Tabel 1. Jumlah individu dari tiap spesies kupu-kupu pada dua wilayah

\begin{tabular}{lclccc}
\hline Nama Famili & No. & Nama spesies & \multicolumn{2}{c}{ Kode Wilayah } & Jumlah \\
\cline { 3 - 4 } & & & DN & CG & Individu \\
\hline I. Hesperiidae & 1 & Udaspes folus & & $\sqrt{ }$ & 2 \\
\hline II. Lycaenidae & 1 & Zizina otis & $\sqrt{ }$ & 1 \\
\hline III. Papilionidae & 1 & Pathysa delessertii & & $\sqrt{ }$ & 1 \\
& 2 & Graphium sarpedon & & $\sqrt{ }$ & 1
\end{tabular}




\begin{tabular}{|c|c|c|c|c|c|}
\hline & 4 & Trogonoptera brookiana & & $\sqrt{ }$ & $\begin{array}{l}\text { Capture } \\
\text { release }\end{array}$ \\
\hline \multirow[t]{12}{*}{ IV. Nymphalidae } & 1 & Mycalesis sp. & $\sqrt{ }$ & & 1 \\
\hline & 2 & Moduza procris & & $\sqrt{ }$ & 1 \\
\hline & 3 & Euploea mulciber & & $\sqrt{ }$ & 3 \\
\hline & 4 & Euploea radamanthus & & $\sqrt{ }$ & 1 \\
\hline & 5 & Cethosia hypsea & & $\sqrt{ }$ & 1 \\
\hline & 6 & Neptis hylas & & $\sqrt{ }$ & 1 \\
\hline & 7 & Doleschallia bisaltide & $\sqrt{ }$ & & 1 \\
\hline & 8 & Melanitis leda & $\sqrt{ }$ & $\sqrt{ }$ & 1 \\
\hline & 9 & Junonia orithya & & $\sqrt{ }$ & 3 \\
\hline & 10 & Elymnias hypermnestra & $\sqrt{ }$ & & 1 \\
\hline & 11 & Hypolimnas bolina jacintha & $\sqrt{ }$ & & 1 \\
\hline & 12 & Lasippa heliodore & $\sqrt{ }$ & & 1 \\
\hline \multirow[t]{4}{*}{ V. Pieridae } & 1 & Appias lyncida & & $\sqrt{ }$ & 3 \\
\hline & 2 & Appias libythea & & $\sqrt{ }$ & 3 \\
\hline & 3 & Hebomoia glaucippe & & $\sqrt{ }$ & 1 \\
\hline & 4 & Delias hyparete & & $\sqrt{ }$ & 3 \\
\hline
\end{tabular}

Keterangan: DN= Danau, CG= Camp Granit

Famili Hesperiidae dan Lycaenidae teramati dalam jumlah yang paling sedikit. Famili Hesperiidae aktif pada pagi dan sore hari untuk menghisap cairan yang berasal dari embun (krepuskular) sehingga tingkat perjumpaan dengan pengamat tergolong jarang (Corbet \& pendlebury 1992; Peggie \& Amir 2006). Kemudian untuk famili Lycaenidae, keberadaan famili ini sangat didukung oleh faktor abiotik, salah satunya adalah intensitas cahaya. Famili Lycaenidae sangat mudah dijumpai pada hari cerah dengan intensitas cahaya yang cukup dan di wilayah terbuka (Peggie 2014), dan didukung oleh tumbuhan inang yang tumbuh di lingkungan terbuka yaitu tumbuhan dari famili Fabaceae dan Rubiaceae (Tabel 2).

Tabel 2. Tumbuhan yang dikunjungi kupu-kupu sebagai vegetasi habitat

\begin{tabular}{|c|c|c|c|c|c|}
\hline \multirow{2}{*}{$\begin{array}{c}\mathbf{N} \\
\mathbf{0}\end{array}$} & \multirow{2}{*}{ Famili } & \multirow{2}{*}{ No } & \multirow{2}{*}{ Spesies } & \multicolumn{2}{|c|}{ Wilayah sampling } \\
\hline & & & & $\mathrm{DN}$ & $\mathrm{CG}$ \\
\hline \multirow[t]{2}{*}{1} & Acanthaceae & 1 & Asystasia gangetica & $\sqrt{ }$ & $\sqrt{ }$ \\
\hline & & 2 & Lindernia anagalis & & $\sqrt{ }$ \\
\hline \multirow[t]{7}{*}{2} & Asteraceae & 1 & Ageratum conyzoides & $\sqrt{ }$ & $\sqrt{ }$ \\
\hline & & 2 & Bidens pilosa & & $\sqrt{ }$ \\
\hline & & 3 & Cyanthillium cinereum & & $\sqrt{ }$ \\
\hline & & 4 & Synedrella nodiflora & $\sqrt{ }$ & $\sqrt{ }$ \\
\hline & & 5 & Cosmos sulphureus & & $\sqrt{ }$ \\
\hline & & 6 & Bidens alba & & $\sqrt{ }$ \\
\hline & & 7 & Chromolaena odorata & $\sqrt{ }$ & \\
\hline 3 & Boraginaceae & 1 & Heliotropium indicum & $\sqrt{ }$ & \\
\hline 4 & Caricaceae & 1 & Carica papaya & & $\sqrt{ }$ \\
\hline 5 & Euphorbeaceae & 1 & Sauropus androgynous & & $\sqrt{ }$ \\
\hline \multirow[t]{4}{*}{6} & Fabaceae & 1 & Mimosa pudica & $\sqrt{ }$ & $\sqrt{ }$ \\
\hline & & 2 & Desmodium heterocarpon & & $\sqrt{ }$ \\
\hline & & 3 & Mimosa diplotricha & $\sqrt{ }$ & \\
\hline & & 4 & Crotalaria anagyroides & & $\sqrt{ }$ \\
\hline 7 & Lauraceae & 1 & Persea Americana & & $\sqrt{ }$ \\
\hline 8 & Limnocharitaceae & 1 & Limnocharis flava & $\sqrt{ }$ & \\
\hline \multirow[t]{2}{*}{9} & Malvaceae & 1 & Sida rhombifolia & $\sqrt{ }$ & $\sqrt{ }$ \\
\hline & & 2 & Urena lobate & & $\sqrt{ }$ \\
\hline
\end{tabular}




\begin{tabular}{|c|c|c|c|c|c|}
\hline 10 & Melastomataceae & $\begin{array}{l}1 \\
2\end{array}$ & $\begin{array}{l}\text { Clidemia hirta } \\
\text { Melastoma malabatricum }\end{array}$ & $\begin{array}{l}\sqrt{ } \\
\sqrt{ }\end{array}$ & $\sqrt{ }$ \\
\hline 11 & Moraceae & 1 & Ficus ampelas & $\sqrt{ }$ & \\
\hline 12 & Myrtaceae & 1 & Psidium guajava & & $\sqrt{ }$ \\
\hline 13 & Orchidaceae & 1 & Arundina graminifolia & $\sqrt{ }$ & $\sqrt{ }$ \\
\hline 14 & Oxalidaceae & 1 & Averrhoa bilimbi & & $\sqrt{ }$ \\
\hline 15 & Polygalaceae & 1 & Polygala paniculata & & $\sqrt{ }$ \\
\hline 16 & Rubiaceae & 1 & Mussaenda frondosa & $\sqrt{ }$ & \\
\hline 17 & Verbenaceae & 1 & Peronema canescens & & $\sqrt{ }$ \\
\hline 18 & Portulacaceae & 1 & Portulaca grandiflora & & $\sqrt{ }$ \\
\hline 19 & Poaceae & 1 & Paspalum conjugatum & & $\sqrt{ }$ \\
\hline 20 & Lamiaceae & 1 & Hyptis capitate & & $\sqrt{ }$ \\
\hline 21 & Cleomaceae & 1 & Cleome rutidosperma & & $\sqrt{ }$ \\
\hline 22 & Rutaceae & 1 & Evodia sp. & $\sqrt{ }$ & \\
\hline Ju & lah spesies & 34 & & 15 & 26 \\
\hline $\mathbf{J u}$ & lah famili & 22 & & 11 & 18 \\
\hline
\end{tabular}

Famili Papilionidea ditemukan sebanyak empat spesies. Vegetasi pada wilayah penangkapan terdapat tumbuhan inang sebagai makanan (foodplant) menjadi faktor utama keberadaan famili Papilionidae. Famili Papilionidea menyukai tumbuhan dari famili Aristolochiacea, Rutacea, Asteracea, Lauraceae dan Annonaceae (Peggie 2014). Namun, pada wilayah hanya tumbuhan dari famili Asteracea dan Rutaceae (Tabel 2). Kupu-kupu spesies Trogonoptera brookiana dari famili Papilionidae pun berhasil ditangkap dan dilepaskan kembali untuk pendataan. Kupu-kupu jenis ini termasuk dalam spesies yang dilindungi oleh Peraturan Menteri Lingkungan Hidup dan Kehutanan No. P.106/MENLHK/SETJEN/KUM.1/12/ 2018. Jenis ini masuk dalam Appendix II CITES (Convention on International Trade in Endangered Species of Wild Fauna and Flora). Menurut IUCN Red List spesies T. brookiana termasuk ke dalam Least concern (resiko rendah). Kupu-kupu dari famili Pieridae dijumpai sebanyak empat spesies pada wilayah penangkapan. Tumbuhan inang dari famili Pieridae cukup melimpah, selain itu juga terdapat adanya aliran sungai sebagai sumber mineral (Lestari et al. 2018). Pieridae umumnya menyukai tanaman berbunga antara lain kelompok Apocynaceae, Asteraceae dan Euphorbiaceae (Peggie \& Amir 2006), Namun pada wilayah penangkapan hanya terdapat tumbuhan dari famili Asteraceae dan Euphorbiaceae (Tabel 2).

Famili Nymphalidae memiliki jumlah spesies tertinggi. Tumbuhan pakan menjadi salah satu faktor kehadiran kupu-kupu di suatu tempat (Busnia 2006). Tumbuhan pakan famili Nymphalidae sangat beragam. Famili Nymphalidae memiliki sifat polyphagus yaitu dapat memakan lebih dari satu jenis tanaman inang dan banyak tersedia spesies tumbuhan sebagai makanan larvanya (Corbet \& Pendlebury 1956). Kemampuan menyesuaikan diri atau beradaptasi pada suatu lingkungan yang cukup tinggi dikarenakan jenis pakan yang beragam (Rahayu \& Basukriadi 2012; Mogan et al. 2018). Sehingga kemungkinan perjumpaan dengan jenis yang lebih beragam dari famili ini semakin besar.

\section{Kondisi Habitat dan Vegetasi dari dua wilayah pengambilan sampel}

Dua wilayah penggambilan sampel kupu-kupu yaitu Danau Mu'un dan Camp Granit didapatkan keberagaman kupu-kupu pada masing-masing wilayah berbeda. Camp Granit memiliki jumlah tangkapan spesies kupu-kupu tertinggi sebanyak 15 spesies kupu-kupu dan Danau mu'un sebanyak tujuh spesies kupu-kupu. Jumlah spesies yang beragam disesuaikan dengan ketersediaan vegetasi dan pakan kupu-kupu tiap wilayah.

Jumlah spesies kupu-kupu di wilayah Camp Granit tergolong tinggi disebabkan vegetasi tumbuhan pakan yang beragam. Tumbuhan yang dominan di Camp Granit yaitu 
famili dari Asteraceae, Acanthaceae, Favaceae dan Malvaceae (Tabel 2). Jumlah spesies yang banyak pada wilayah Camp Granit juga didukung oleh keadaan lingkungan yang disukai oleh kupu-kupu yaitu intensitas cahaya cukup yaitu $28083 \mathrm{Lux}$, suhu $31,7{ }^{\circ} \mathrm{C}$ dan kelembaban 59,7 \% (Tabel 3). Ketersediaan sumber air yang diperlukan oleh kupu-kupu sebagai tempat untuk mendapatkan sumber mineral menjadi salah satu faktor keberagaman kupu-kupu pada danau Mu'un (Sihombing 2002).

Tabel 3. Hasil pengukuran faktor fisika di wilayah penangkapan kupu-kupu.

\begin{tabular}{ccccccccccccc}
\hline Wilayah & \multicolumn{1}{c}{ Faktor Fisika } \\
\cline { 2 - 14 } & \multicolumn{4}{c}{ Intensitas Cahaya } & \multicolumn{1}{c}{ Suhu } & \multicolumn{1}{c}{ Kelembapan } \\
\cline { 2 - 13 } & 1 & 2 & 3 & Rerata & 1 & 2 & 3 & Rerata & 1 & 2 & 3 & Rerata \\
\hline Danau Mu'un & 5121 & 8345 & 4350 & 5938 & 27 & 29 & 27 & 27,7 & 66 & 65 & 66 & 65,7 \\
Camp Granit & 29400 & 31150 & 23700 & 28083 & 31 & 35 & 29 & 31,7 & 65 & 42 & 72 & 59,7 \\
\hline
\end{tabular}

Danau mu'un memiliki jumlah spesies kupu-kupu paling sedikit disebabkan oleh kondisi habitat yang kurang disukai oleh kupu-kupu yaitu intensitas cahaya cukup rendah 5938 Lux (Tabel 4). Intensitas cahaya yang rendah cukup mempengaruhi keberagaman kupu-kupu. Jumlah spesies kupu-kupu dipengaruhi tutupan kanopi pohon dan intensitas cahaya matahari (Koh \& Sodhi 2004). Kelimpahan spesies kupu-kupu yang ditemukan berbeda disebabkan oleh kurangnya tanaman inang yang menjadi sumber makanan dari spesies kupu-kupu tersebut.

Jumlah spesies kupu-kupu yang tinggi pada suatu wilayah juga dipengaruhi faktor abiotik seperti suhu, kelembaban udara serta intensitas cahaya. Faktor lingkungan yang sesuai untuk kupu-kupu beraktivitas terdapat pada suhu $15-45^{\circ} \mathrm{C}$ (Jumar 2000). Suhu optimal berbeda pada setiap jenis tidak sama, tergantung pada lokasi dan jenis kupu-kupu (Gusnenti 2010). Intensitas cahaya dari dua wilayah yaitu berkisar 5938-28083 lux (Tabel 3). Faktor lingkungan yang sesuai untuk kupu-kupu terdapat pada intensitas cahaya 20007500 lux (Nurjanah 2010). Namun, setiap jenis kupu-kupu memiliki nilai optimal cahaya berbeda sesuai dengan lingkungan dan morfologi tubuh. Adaptasi kupu-kupu yang selalu membutuhkan sinar matahari untuk berjemur (Panjaitan 2011). Kupu-kupu aktif pada hari yang cerah, hangat, dan tenang (Peggie \& Amir 2006). Kelembaban udara merupakan faktor lingkungan yang juga mempengaruhi aktivitas kupu-kupu dalam mencari pakan. Kupu-kupu dan ulat menghindari kondisi yang kering dan mencari tempat dengan kelembaban yang cukup untuk beristirahat. Hasil rerata kelembapan berkisar 59\% - 66\% (Tabel 4). Hal ini sesuai dengan kelembapan udara lingkungan kupu-kupu optimal yaitu berkisar 60\%-75\% (Kingsolver 1985 dalam Ariani 2013).

\section{Karakteristik Morfologi Kupu-kupu}

\section{Karakteristik Morfologi Spesies dari Famili Hesperiidae}

\section{Udaspes folus}

Deskripsi : Warna kepala hitam (N 2), panjang kepala 2,6 mm. Warna antena coklat (10YR 3/6), panjang antena $11,0 \mathrm{~mm}$, bentuk antena ujung meruncing. Warna proboscis hitam (N 2). Warna labial pulp putih (N 9.5), panjang labial pulp 2,5 mm. Warna dada atas hitam (10YR 2.3/2.5), warna dada bawah putih (N 9.5), panjang dada 6,1 mm. Warna tungkai putih (N 9.5), panjang tungkai depan 10,1 mm, panjang tungkai tengah 120 $\mathrm{mm}$, panjang tungkai belakang 13,3 mm. Warna utama sayap atas hitam (10YR 2.3/2.5), warna utama sayap bawah hitam (10YR 2.3/2.5), panjang sayap depan 14,3 mm, panjang sayap belakang 13,4 mm, lebar sayap depan 20,9 mm, lebar sayap belakang 17,6 mm, panjang rentang sayap $46,3 \mathrm{~mm}$, bentuk ujung sayap atas meruncing, bentuk tepian sayap 
bawah halus. Warna perut atas hitam (10YR 2.3/2.5), warna perut bawah putih (N 9.5), panjang perut $11,0 \mathrm{~mm}$.

(Kode Spesimen: UF1CG19. Waktu Koleksi: 2019. Kolektor: Appriliya Destiyana, Muhammad Ali Nafiah, Jodi Saputra).

\section{Karakteristik Morfologi Spesies dari Famili Lycaenidae}

\section{Zizina Otis}

Deskripsi : Warna kepala hitam (N 2), panjang kepala 0,8 $\mathrm{mm}$. Warna antena hitam (N 2), panjang antena $5,9 \mathrm{~mm}$, bentuk antena ujung membulat. Warna proboscis hitam $(\mathrm{N}$ 2), Warna labial pulp putih (N 9.5), panjang labial pulp 1,7 mm. Warna dada atas hitam (N 2), warna dada bawah putih ( $\mathrm{N}$ 9.5), panjang dada 2,4 $\mathrm{mm}$. Warna tungkai putih ( $\mathrm{N} 9.5$ ), panjang tungkai depan $4,0 \mathrm{~mm}$, panjang tungkai tengah $4,0 \mathrm{~mm}$, panjang tungkai belakang 4,2 $\mathrm{mm}$. Warna utama sayap atas ungu (10PB 9/2), warna utama sayap bawah putih (7.5Y 9/2), panjang sayap depan 7,0 $\mathrm{mm}$, panjang sayap belakang $5,5 \mathrm{~mm}$, lebar sayap depan $10,1 \mathrm{~mm}$, lebar sayap belakang $8,1 \mathrm{~mm}$, panjang rentang sayap $22,3 \mathrm{~mm}$, bentuk ujung sayap atas membulat, bentuk tepian sayap bawah halus. Warna perut atas hitam (N 2), warna perut bawah putih (N 9.5), panjang perut 4,9 $\mathrm{mm}$.

(Kode Spesimen: ZO1CG19. Waktu Koleksi: 2019. Kolektor: Appriliya Destiyana, Muhammad Ali Nafiah, Jodi Saputra).

\section{Karakteristik Morfologi Spesies dari Famili Nymphalidae 1. Mycalesis sp.}

Deskripsi : Warna kepala coklat (10YR 2.3/2.5), panjang kepala 1,0 mm. Warna antena coklat (10YR 4/4), panjang antena $9,7 \mathrm{~mm}$, bentuk antena tali. Warna proboscis coklat (10YR 2.3/2.5), Warna labial pulp coklat (5Y 8/2), panjang labial pulp 2,8 mm. Warna dada atas coklat (10YR 4/4), warna dada bawah coklat (10YR 4/6), panjang dada $56 \mathrm{~mm}$. Warna tungkai coklat (10YR 4.5/2), panjang tungkai depan -, panjang tungkai tengah $9,1 \mathrm{~mm}$, panjang tungkai belakang $7,8 \mathrm{~mm}$. Warna utama sayap atas coklat (10YR 4/4), warna utama sayap bawah coklat (10YR 4/6), panjang sayap depan 12,8 $\mathrm{mm}$, panjang sayap belakang $15,3 \mathrm{~mm}$, lebar sayap depan $20,7 \mathrm{~mm}$, lebar sayap belakang $16,7 \mathrm{~mm}$, panjang rentang sayap $45,9 \mathrm{~mm}$, bentuk ujung sayap atas membulat, bentuk tepian sayap bawah halus. Warna perut atas coklat (10YR 4/4), warna perut bawah coklat (10YR 4/6), panjang perut $9,0 \mathrm{~mm}$.

(Kode Spesimen: M1DN19. Waktu Koleksi: 2019. Kolektor: Appriliya Destiyana, Muhammad Ali Nafiah, Jodi Saputra).

\section{Moduza procris}

Deskripsi : Warna kepala coklat (5R 2.3/2.5), panjang kepala 3,3 mm. Warna antena coklat (10YR 4/4), panjang antena $18,1 \mathrm{~mm}$, bentuk antena tali. Warna proboscis coklat (10YR 2.3/2.5), Warna labial pulp putih (N 9.5), panjang labial pulp 2,2 $\mathrm{mm}$. Warna dada atas coklat (10YR 2.3/2.5), warna dada bawah putih (N 8.5), panjang dada 9,1 mm. Warna tungkai putih (N 9.5), panjang tungkai depan -, panjang tungkai tengah 16,4 mm, panjang tungkai belakang 14,5 mm. Warna utama sayap atas hitam kecoklatan (2.5 YR 2.3/2.5), warna utama sayap bawah puth $(2.5 \mathrm{GY} 9 / 2)$, panjang sayap depan $22,7 \mathrm{~mm}$, panjang sayap belakang 21,5 mm, lebar sayap depan $29,1 \mathrm{~mm}$, lebar sayap belakang $23,8 \mathrm{~mm}$, panjang rentang sayap $66,2 \mathrm{~mm}$, bentuk ujung sayap atas meruncing, bentuk tepian sayap bawah bergelombang. Warna perut atas coklat (10YR 2.3/2.5), warna perut bawah putih (N 8.5 ), panjang perut $10,4 \mathrm{~mm}$. 
(Kode Spesimen: MP1CG19. Waktu Koleksi: 2019. Kolektor: Appriliya Destiyana, Muhammad Ali Nafiah, Jodi Saputra).

\section{Euploea mulciber}

Deskripsi : Warna kepala hitam (N 1), Panjang kepala 2,0 mm, Warna antena hitam (N 1), Panjang antena 15,1 mm, Bentuk antena tali, Warna proboscis hitam (N 2), Warna labial pulp coklat (5Y 8/2), Panjang labial pulp 2,4 mm, Warna dada atas Hitam (N 2), Warna dada bawah hitam (N 1), Panjang dada 6,2 mm, Warna tungkai hitam (N 1), Panjang tungkai depan , Panjang tungkai tengah 16,3 mm, Panjang tungkai belakang 15,2 $\mathrm{mm}$, Warna utama sayap atas biru (2,5 P), Warna utama sayap bawah Hitam (10 YR 2,3/2,5), Panjang sayap depan 44,2 $\mathrm{mm}$, Panjang sayap belakang $28,1 \mathrm{~mm}$, Lebar sayap depan 44,2 $\mathrm{mm}$, Lebar sayap belakang 29,0 $\mathrm{mm}$, panjang rentang sayap 96,5 $\mathrm{mm}$, bentuk ujung sayap atas membulat, Bentuk tepian sayap bawah halus, Warna perut atas hitam (N 1), Warna perut bawah hitam (N 1), Panjang perut 17,3 mm.

(Kode Spesimen: EMj1CG19. Waktu Koleksi: 2019. Kolektor: Appriliya Destiyana, Muhammad Ali Nafiah, Jodi Saputra).

\section{Euploea radamanthus}

Deskripsi : Warna kepala hitam (N 1), panjang kepala 2,2 $\mathrm{mm}$. Warna antena hitam (N 2), panjang antena $14,0 \mathrm{~mm}$, bentuk antena tali. Warna proboscis hitam (N 2), Warna labial pulp hitam (N 2), panjang labial pulp 2,5 $\mathrm{mm}$. Warna dada atas hitam (N 1), warna dada bawah hitam (N 1), panjang dada $8,1 \mathrm{~mm}$. Warna tungkai hitam (N 1), panjang tungkai depan -, panjang tungkai tengah $12,3 \mathrm{~mm}$, panjang tungkai belakang 12,8 $\mathrm{mm}$. Warna utama sayap atas hitam (N 1), warna utama sayap bawah coklat (5Y 3.3/4), panjang sayap depan 25,8 mm, panjang sayap belakang $28,6 \mathrm{~mm}$, lebar sayap depan 35,8 mm, lebar sayap belakang $25,5 \mathrm{~mm}$, panjang rentang sayap $80,7 \mathrm{~mm}$, bentuk ujung sayap atas membulat, bentuk tepian sayap bawah halus. Warna perut atas hitam ( $\mathrm{N} 1)$, warna perut bawah hitam (N 1), panjang perut 19,0 mm.

(Kode Spesimen: ER1CG19. Waktu Koleksi: 2019. Kolektor: Appriliya Destiyana, Muhammad Ali Nafiah, Jodi Saputra).

\section{Cethosia hypsea}

Deskripsi : Warna kepala hitam (N 2), panjang kepala 2,2 $\mathrm{mm}$. Warna antena hitam (N 2), panjang antena 20,0 mm, bentuk antena tali. Warna proboscis coklat (10YR 2.3/2.5), Warna labial pulp putih (N 9.5), panjang labial pulp 2,8. Warna dada atas coklat (10YR 2.3/2.5), warna dada bawah putih ( $\mathrm{N} 8.5$ ), panjang dada $8,0 \mathrm{~mm}$. Warna tungkai coklat muda (10YR 9/2), panjang tungkai depan -, panjang tungkai tengah 9,4 mm, panjang tungkai belakang $17,4 \mathrm{~mm}$. Warna utama sayap atas hitam ( $\mathrm{N}$ 2), warna utama sayap bawah merah keorenan (10R 6/12), panjang sayap depan 27,0 mm, panjang sayap belakang $31,3 \mathrm{~mm}$, lebar sayap depan 43,5 $\mathrm{mm}$, lebar sayap belakang $33,3 \mathrm{~mm}$, panjang rentang sayap 92,1 mm, bentuk ujung sayap atas meruncing, bentuk tepian sayap bawah bergelombang. Warna perut atas orange (7.5YR 7/15), warna perut bawah orange (7.5YR 7/15), panjang perut $15,4 \mathrm{~mm}$.

(Kode Spesimen: CH1CG19. Waktu Koleksi: 2019. Kolektor: Appriliya Destiyana, Muhammad Ali Nafiah, Jodi Saputra).

\section{Neptis hylas}

Deskripsi

: Warna kepala hitam (N 2), panjang kepala 3,3 mm. Warna antena coklat (5Y 6/6.5), panjang antena $11,3 \mathrm{~mm}$, bentuk antena tali. Warna proboscis coklat (1Y 4/6), Warna labial pulp putih (N 9.5), panjang labial pulp 2,5 mm. Warna dada atas hitam (N 1), warna dada bawah putih (10 YR 9/8.0), panjang dada 5,8 mm. Warna tungkai coklat muda (10YR 9/2), panjang tungkai depan -, panjang tungkai tengah 9,2 mm, panjang tungkai belakang $9,8 \mathrm{~mm}$. Warna utama sayap atas hitam $(\mathrm{N} \mathrm{1})$, warna utama sayap bawah coklat (10 YR 6/6.5), panjang sayap depan 12,6 mm, panjang sayap belakang 18,1 mm, 
lebar sayap depan 22,7 mm, lebar sayap belakang 24,6 mm, panjang rentang sayap 52,6 $\mathrm{mm}$, bentuk ujung sayap atas membulat, bentuk tepian sayap bawah gelombang. Warna perut atas hitam (N 1), warna perut bawah putih (10 YR 9/8.0), panjang perut 9,0 mm.

(Kode Spesimen: NH1CG19. Waktu Koleksi: 2019. Kolektor: Appriliya Destiyana, Muhammad Ali Nafiah, Jodi Saputra).

\section{Doleschallia bisaltide}

Deskripsi : Warna kepala coklat (10YR 4/8), panjang kepala 2,9 mm. Warna antena coklat (10YR 2.3/2.5), panjang antena $16,5 \mathrm{~mm}$, bentuk antena ujung membulat. Warna proboscis coklat (10YR 2.3/2.5), Warna labial pulp putih (N 9.5), panjang labial pulp 4,0 mm. Warna dada atas coklat (10YR 4/8), warna dada bawah coklat (10YR 6.6/5), panjang dada 10,1 mm. Warna tungkai coklat (10YR 9/2), panjang tungkai depan -, panjang tungkai tengah $20,1 \mathrm{~mm}$, panjang tungkai belakang $17,5 \mathrm{~mm}$. Warna utama sayap atas orange (7.5YR 7/12), warna utama sayap bawah coklat (10YR 2.3/2.5), panjang sayap depan 25,0 mm, panjang sayap belakang $29,7 \mathrm{~mm}$, lebar sayap depan $281 \mathrm{~mm}$, lebar sayap belakang $26,3 \mathrm{~mm}$, panjang rentang sayap $71,9 \mathrm{~mm}$, bentuk ujung sayap atas meruncing, bentuk tepian sayap bawah perpanjangan/ekor. Warna perut atas coklat (10YR 6.6/5), warna perut bawah coklat (10YR 6.6/5), panjang perut 10,1 mm.

(Kode Spesimen: DB1DN19. Waktu Koleksi: 2019. Kolektor: Appriliya Destiyana, Muhammad Ali Nafiah, Jodi Saputra).

\section{Melanitis leda}

Deskripsi : Warna kepala coklat (10YR 3/6), panjang kepala 2,5 mm. Warna antena coklat (10YR 5/8), panjang antena $11,3 \mathrm{~mm}$, bentuk antena tali. Warna proboscis coklat (7.5YR 4/6), Warna labial pulp putih (N 8), panjang labial pulp 2,7 mm. Warna dada atas coklat (10YR 3/6), warna dada bawah coklat (7.5Y 9/2), panjang dada $6,4 \mathrm{~mm}$. Warna tungkai coklat (7.5Y 9/2), panjang tungkai depan -, panjang tungkai tengah 14,6 mm, panjang tungkai belakang $15,6 \mathrm{~mm}$. Warna utama sayap atas coklat (10YR 3/6), warna utama sayap bawah coklat (7.5Y 9/2), panjang sayap depan $25,1 \mathrm{~mm}$, panjang sayap belakang $26,3 \mathrm{~mm}$, lebar sayap depan $35,3 \mathrm{~mm}$, lebar sayap belakang $32,9 \mathrm{~mm}$, panjang rentang sayap 71,1 mm, bentuk ujung sayap atas meruncing, bentuk tepian sayap bawah perpanjangan/ekor. Warna perut atas coklat (10YR 3/6), warna perut bawah coklat (7.5Y 9/2), panjang perut $10,6 \mathrm{~mm}$.

(Kode Spesimen: MLdry1DN19 . Waktu Koleksi: 2019. Kolektor: Appriliya Destiyana, Muhammad Ali Nafiah, Jodi Saputra).

\section{Junonia orithya}

Deskripsi : Warna kepala hitam (5YR 2.8/6), panjang kepala 2,1 mm. Warna antena putih (5YR 8/2), panjang antena $12,6 \mathrm{~mm}$, bentuk antena ujung membulat. Warna proboscis coklat (10YR 5/6.5), Warna labial pulp putih (N 8), panjang labial pulp 3,8 mm. Warna dada atas hitam (N 2), warna dada bawah putih (10YR 9/0.8), panjang dada 6,5 mm. Warna tungkai putih (10YR 9/0.8), panjang tungkai depan -, panjang tungkai tengah $14,2 \mathrm{~mm}$, panjang tungkai belakang $15,3 \mathrm{~mm}$. Warna utama sayap atas hitam ( $\mathrm{N} \mathrm{1})$, warna utama sayap bawah coklat (10YR 7/4), panjang sayap depan $18,1 \mathrm{~mm}$, panjang sayap belakang 19,7 mm, lebar sayap depan 24,1 mm, lebar sayap belakang 20,6 mm, panjang rentang sayap 56,1 mm, bentuk ujung sayap atas membulat, bentuk tepian sayap bawah halus. Warna perut atas hitam (N 2), warna perut bawah coklat (10YR 7/4), panjang perut 9,8 mm.

(Kode Spesimen: JOj1CG19. Waktu Koleksi: 2019. Kolektor: Appriliya Destiyana, Muhammad Ali Nafiah, Jodi Saputra).

\section{Elymnias hypermnestra}

Deskripsi : Warna kepala coklat (1Y 2.3/2.5), panjang kepala 2,1 mm. Warna antena coklat (10YR 2.3/2.5), panjang antena $14,2 \mathrm{~mm}$, bentuk antena tali. Warna proboscis 
coklat (7.5YR 4/6), Warna labial pulp coklat (2.5YR 2.3/2.5), panjang labial pulp 3,0 mm. Warna dada atas coklat (1Y 2.3/2.5), warna dada bawah coklat (1Y 7/4), panjang dada 8,1 $\mathrm{mm}$. Warna tungkai coklat (2.5Y 4/4), panjang tungkai depan -, panjang tungkai tengah $10,2 \mathrm{~mm}$, panjang tungkai belakang $12,2 \mathrm{~mm}$. Warna utama sayap atas coklat $(2.5 \mathrm{R}$ 2.3/4), warna utama sayap bawah coklat (2.5YR 2.3/4), panjang sayap depan 25,0 mm, panjang sayap belakang $26,0 \mathrm{~mm}$, lebar sayap depan $32,2 \mathrm{~mm}$, lebar sayap belakang 29,8 $\mathrm{mm}$, panjang rentang sayap $75,4 \mathrm{~mm}$, bentuk ujung sayap atas membulat, bentuk tepian sayap bawah gelombang. Warna perut atas coklat (1Y 2.3/2.5), warna perut bawah coklat (1Y 7/4), panjang perut $10,7 \mathrm{~mm}$.

(Kode Spesimen: EH1DN19. Waktu Koleksi: 2019. Kolektor: Appriliya Destiyana, Muhammad Ali Nafiah, Jodi Saputra).

\section{Lasippa heliodore}

Deskripsi : Warna kepala hitam (N 1), panjang kepala 1,5 mm. Warna antena hitam (N 1), panjang antena $12,1 \mathrm{~mm}$, bentuk antena ujung tali. Warna proboscis coklat (7.5YR 4/6), Warna labial pulp putih (N 8), panjang labial pulp 2,4 $\mathrm{mm}$. Warna dada atas hitam (N 1), warna dada bawah coklat (7.5YR 9/2), panjang dada 4,0 mm. Warna tungkai coklat (7.5YR 9/2), panjang tungkai depan $23 \mathrm{~mm}$, panjang tungkai tengah 2,8 $\mathrm{mm}$, panjang tungkai belakang $5,9 \mathrm{~mm}$. Warna utama sayap atas orange (7.5YR 7/12), warna utama sayap bawah coklat (7.5YR 2.8/4), panjang sayap depan $13,8 \mathrm{~mm}$, panjang sayap belakang 15,6 mm, lebar sayap depan 21,4 $\mathrm{mm}$, lebar sayap belakang $16,3 \mathrm{~mm}$, panjang rentang sayap 45,1 mm, bentuk ujung sayap atas membulat, bentuk tepian sayap bawah halus. Warna perut atas hitam (N 1), warna perut bawah coklat (7.5YR 9/2), panjang perut 7,3 $\mathrm{mm}$.

(Kode Spesimen: LH1DN19. Waktu Koleksi: 2019. Kolektor: Appriliya Destiyana, Muhammad Ali Nafiah, Jodi Saputra).

\section{Hypolimnas bolina jacintha}

Deskripsi : Warna kepala hitam (N 1), panjang kepala 2,3 $\mathrm{mm}$. Warna antena coklat (7.5YR 2.3/2.5), panjang antena $16,5 \mathrm{~mm}$, bentuk antena ujung membulat. Warna proboscis hitam (N 1), Warna labial pulp putih (N 8), panjang labial pulp 3,9 $\mathrm{mm}$. Warna dada atas hitam (N 1), warna dada bawah coklat (7.5YR 4/6), panjang dada 6,1 mm. Warna tungkai hitam (N 2), panjang tungkai depan -, panjang tungkai tengah 12,2 mm, panjang tungkai belakang 10,3 mm. Warna utama sayap atas hitam (N 1), warna utama sayap bawah coklat (7.5YR 4/8), panjang sayap depan $24,4 \mathrm{~mm}$, panjang sayap belakang 26,7 $\mathrm{mm}$, lebar sayap depan $388 \mathrm{~mm}$, lebar sayap belakang 29,6 mm, panjang rentang sayap $89,5 \mathrm{~mm}$, bentuk ujung sayap atas membulat, bentuk tepian sayap bawah bergelombang. Warna perut atas hitam (N 1), warna perut bawah coklat (7.5YR 4/8), panjang perut 14,1 $\mathrm{mm}$.

(Kode Spesimen: HBJ1DN19. Waktu Koleksi: 2019. Kolektor: Appriliya Destiyana, Muhammad Ali Nafiah, Jodi Saputra).

\section{Karakteristik Morfologi Spesies dari Famili Papilionidae 1. Graphium sarpedon}

Deskrispsi : Warna kepala hitam (N 2), panjang kepala 2,3 $\mathrm{mm}$. Warna antena hitam (N 1.5), panjang antena $14,1 \mathrm{~mm}$, bentuk antena ujung membulat. Warna proboscis hitam (N 2), Warna labial pulp putih (N 8), panjang labial pulp 3,0 $\mathrm{mm}$. Warna dada atas hitam (N 1), warna dada bawah hitam (N 2), panjang dada $8,3 \mathrm{~mm}$. Warna tungkai hitam (N 2), panjang tungkai depan $11,2 \mathrm{~mm}$, panjang tungkai tengah $12,3 \mathrm{~mm}$, panjang tungkai belakang $144 \mathrm{~mm}$. Warna utama sayap atas hitam (N 1), warna utama sayap bawah hitam (N 2), panjang sayap depan $27,1 \mathrm{~mm}$, panjang sayap belakang $23,2 \mathrm{~mm}$, lebar sayap depan $35,1 \mathrm{~mm}$, lebar sayap belakang $27,1 \mathrm{~mm}$, panjang rentang sayap $80,2 \mathrm{~mm}$, bentuk ujung 
sayap atas meruncing, bentuk tepian sayap bawah bergelombang. Warna perut atas hitam (N 1), warna perut bawah hitam (N 6), panjang perut 10,0 mm.

(Kode Spesimen: GS1CG19. Waktu Koleksi: 2019. Kolektor: Appriliya Destiyana, Muhammad Ali Nafiah, Jodi Saputra).

\section{Graphium antiphates}

Deskripsi : Warna kepala hitam (N 3), panjang kepala 2,2 $\mathrm{mm}$. Warna antena hitam (N 2), panjang antena $8,1 \mathrm{~mm}$, bentuk antena ujung membulat. Warna proboscis hitam $(\mathrm{N}$ 3), Warna labial pulp putih (N 8), panjang labial pulp 2,8 $\mathrm{mm}$. Warna dada atas abu-abu (N 7,5), warna dada bawah kuning (10 Y 9/2), panjang dada 5,1 mm. Warna tungkai hitam kehijauan (10 Y 4,5/2), panjang tungkai depan $8,0 \mathrm{~mm}$, panjang tungkai tengah $9,1 \mathrm{~mm}$, panjang tungkai belakang 13,2 mm. Warna utama sayap atas kuning (10 Y 9/2), warna utama sayap bawah kuning (5Y 9/6), panjang sayap depan 26,1 $\mathrm{mm}$, panjang sayap belakang 19,3 mm, lebar sayap depan 34,0 mm, lebar sayap belakang 24,0 mm, panjang rentang sayap $82,8 \mathrm{~mm}$, bentuk ujung sayap atas meruncing, bentuk tepian sayap bawah perpanjangan/berekor. Warna perut atas kuning (10 Y 9/2), warna perut bawah kuning (10 Y 9/2), panjang perut 7,3 $\mathrm{mm}$.

(Kode Spesimen: GA1CG19. Waktu Koleksi: 2019. Kolektor: Appriliya Destiyana, Muhammad Ali Nafiah, Jodi Saputra).

\section{Pathysa delessertii}

Deskripsi : Warna kepala hitam (N 1), panjang kepala 4,2 $\mathrm{mm}$. Warna antena coklat (10 YR 2.3/2.5), panjang antena $12,2 \mathrm{~mm}$, bentuk antena ujung membulat. Warna proboscis coklat (10 YR 2.3/2.5), Warna labial pulp putih (N 8), panjang labial pulp 2,7 $\mathrm{mm}$. Warna dada atas hitam (N 1) dan abu-abu (N 8), warna dada bawah hitam (N 1) dan putih (N 9.5), panjang dada $6,1 \mathrm{~mm}$. Warna tungkai hitam (10Y 2.3/2.5), panjang tungkai depan 7,2 mm, panjang tungkai tengah $111 \mathrm{~mm}$, panjang tungkai belakang 16,2 $\mathrm{mm}$. Warna utama sayap atas hitam ( $\mathrm{N} 1)$, warna utama sayap bawah hitam (N 1), panjang sayap depan $36,2 \mathrm{~mm}$, panjang sayap belakang $26,1 \mathrm{~mm}$, lebar sayap depan 44,0 mm, lebar sayap belakang 29,1 mm, panjang rentang sayap 104,2 mm, bentuk ujung sayap atas meruncing, bentuk tepian sayap bawah bergelombang. Warna perut atas hitam (N 1), warna perut bawah putih (N 9.5), panjang perut $15,1 \mathrm{~mm}$.

(Kode Spesimen: PD1DN19. Waktu Koleksi: 2019. Kolektor: Appriliya Destiyana, Muhammad Ali Nafiah, Jodi Saputra).

\section{Karakteristik Morfologi Spesies dari Famili Pieridae \\ 1. Appias lyncida}

Deskripsi : Warna kepala hitam (N 1), panjang kepala 3,0 mm. Warna antena hitam (N 2), panjang antena $14,2 \mathrm{~mm}$, bentuk antena ujung membulat. Warna proboscis hitam ( $\mathrm{N}$ 1), Warna labial pulp putih (N 8), panjang labial pulp 2,5 $\mathrm{mm}$. Warna dada atas hitam (N

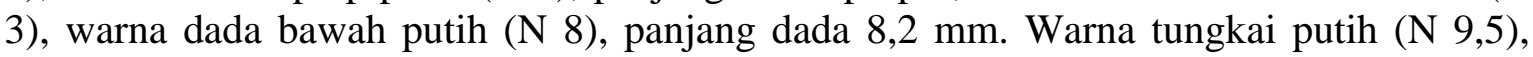
panjang tungkai depan $9,2 \mathrm{~mm}$, panjang tungkai tengah $12,5 \mathrm{~mm}$, panjang tungkai belakang 12,8 mm. Warna utama sayap atas putih (N 9), warna utama sayap bawah kuning , panjang sayap depan 24,1 mm, panjang sayap belakang 21,6 mm, lebar sayap depan, 29,8 $\mathrm{mm}$ lebar sayap belakang 20,5 $\mathrm{mm}$, panjang rentang sayap $61,2 \mathrm{~mm}$, bentuk ujung sayap atas membulat, bentuk tepian sayap bawah halus. Warna perut atas hitam (N 3), warna perut bawah putih (N 8), panjang perut 14,2 mm.

(Kode Spesimen: ALYJ1CG19. Waktu Koleksi: 2019. Kolektor: Appriliya Destiyana, Muhammad Ali Nafiah, Jodi Saputra).

\section{Appias libythea}

Deskripsi : Warna kepala hitam (N 1), panjang kepala 1,7 mm. Warna antena hitam (N 3), panjang antena $11,3 \mathrm{~mm}$, bentuk antena ujung membulat. Warna proboscis hitam $(\mathrm{N}$ 
1), Warna labial pulp putih ( $\mathrm{N} 8$ ), panjang labial pulp 1,7. Warna dada atas hitam (N 2),

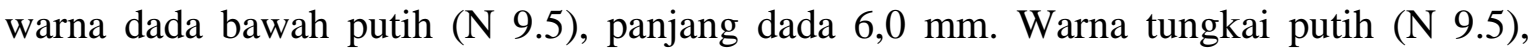
panjang tungkai depan 3,1 mm, panjang tungkai tengah 4,0 mm, panjang tungkai belakang 3,8 mm. Warna utama sayap atas putih (N 5), warna utama sayap bawah putih (N 5), panjang sayap depan $188 \mathrm{~mm}$, panjang sayap belakang $17,9 \mathrm{~mm}$, lebar sayap depan 24,5 $\mathrm{mm}$, lebar sayap belakang $1,92 \mathrm{~mm}$, panjang rentang sayap $57,5 \mathrm{~mm}$, bentuk ujung sayap atas meruncing, bentuk tepian sayap bawah halus. Warna perut atas, hitam (N 2), warna perut bawah putih (N 5), panjang perut $11,3 \mathrm{~mm}$.

(Kode Spesimen: ALI1AT19. Waktu Koleksi: 2019. Kolektor: Appriliya Destiyana, Muhammad Ali Nafiah, Jodi Saputra).

\section{Hebomoia glaucippe}

Deskripsi : Warna kepala coklat (1Y 3.5/6), panjang kepala 3,0 $\mathrm{mm}$. Warna antena hitam (N 2), panjang antena $14,5 \mathrm{~mm}$, bentuk antena ujung membulat. Warna proboscis hitam (N 2), Warna labial pulp coklat (2.5YR 2.3/2.5), panjang labial pulp 3,2 mm. Warna dada atas putih (5Y 9/0.8), warna dada bawah kuning (5Y 8/6), panjang dada $8,1 \mathrm{~mm}$. Warna tungkai kuning (5Y 8/6), panjang tungkai depan $17,8 \mathrm{~mm}$, panjang tungkai tengah $32,0 \mathrm{~mm}$, panjang tungkai belakang $23,5 \mathrm{~mm}$. Warna utama sayap atas putih (5Y 9/0.8), warna utama sayap bawah kuning (5Y 8/6), panjang sayap depan 20,1 mm, panjang sayap belakang 23,0 $\mathrm{mm}$, lebar sayap depan $36,0 \mathrm{~mm}$, lebar sayap belakang $37,4 \mathrm{~mm}$, panjang rentang sayap 105,8 mm, bentuk ujung sayap atas meruncing, bentuk tepian sayap bawah halus. Warna perut atas putih (5Y 9/0.8), warna perut bawah kuning (5Y 8/6), panjang perut $12,6 \mathrm{~mm}$.

(Kode Spesimen: HG1CG19. Waktu Koleksi: 2019. Kolektor: Appriliya Destiyana, Muhammad Ali Nafiah, Jodi Saputra).

\section{Delias hyparete}

Deskripsi : Warna kepala hitam (N 4), panjang kepala 2,5 mm. Warna antena hutam (N 4), panjang antena $15,5 \mathrm{~mm}$, bentuk antena ujung membulat. Warna proboscis hitam ( $\mathrm{N}$ 2), Warna labial pulp putih (N 8), panjang labial pulp 3,0 $\mathrm{mm}$. Warna dada atas abu-abu (N 7), warna dada bawah kuning muda (5Y 9/6), panjang dada 5,8 $\mathrm{mm}$. Warna tungkai hitam (N 4), panjang tungkai depan $6,2 \mathrm{~mm}$, panjang tungkai tengah $8,2 \mathrm{~mm}$, panjang tungkai belakang $8,5 \mathrm{~mm}$. Warna utama sayap atas hitam (N 6), warna utama sayap bawah hitam (N 7), panjang sayap depan $23,6 \mathrm{~mm}$, panjang sayap belakang $22,7 \mathrm{~mm}$, lebar sayap depan $37,0 \mathrm{~mm}$, lebar sayap belakang $31,7 \mathrm{~mm}$, panjang rentang sayap $83,3 \mathrm{~mm}$, bentuk ujung sayap atas membulat, bentuk tepian sayap bawah halus. Warna perut atas putih (N 9.5), warna perut bawah putih (N 9.5), panjang perut $13,0 \mathrm{~mm}$.

(Kode Spesimen: DH1DN19. Waktu Koleksi: 2019. Kolektor: Appriliya Destiyana, Muhammad Ali Nafiah, Jodi Saputra).

\section{KESIMPULAN DAN SARAN}

Jumlah spesies kupu-kupu yang berhasil tertangkap dari dua wilayah di Resort Talang Lakat Zona Pemanfaatan TNBT Provinsi Riau sebanyak 22 spesies dan lima famili. Total keseluruhan individu kupu-kupu dari dua wilayah adalah 32 individu. Jenis kupukupu yang paling banyak ditemukan yaitu dari famili Nymphalidae sebanyak sembilan spesies, famili Papilionidae empat spesies, Pieridae empat spesies, famili Lycaenidae dan Hesperiidae masing-masing satu spesies.

Karakteristik morfologi yang berhasil diamati terdiri dari kepala, dada, perut, tungkai dan sayap kupu-kupu. Karakteristik bentuk antena yang ada di kepala yaitu bentuk antena membulat dan tali. Warna dada pada kupu-kupu di dominasi oleh warna hitam dan coklat. Karakteristik warna pada bagian perut dan tungkai di dominasi warna hitam, coklat, kuning dan putih. Karakteristik pada bagian sayap berupa bentuk pola warna sayap yaitu 
spotted/bercak, eyespot/bintik mata, plain/warna tunggal dan colour band/pita warna, kemudian bentuk tepian sayap bawah yaitu halus, bergelombang dan berekor, selanjutnya bentuk ujung sayap atas yaitu meruncing dan melengkung.

Camp Granit memiliki jumlah tumbuhan yang dikunjungi kupu-kupu lebih banyak dibandingkan Danau mu'un. Pada wilayah sampel yaitu Camp Granit didapatkan jumlah tumbuhan sebanyak 26 spesies dari 18 famili, sedangkan Danau Mu'un sebanyak 15 spesies dari 11 famili. Perbedaan jumlah tumbuhan yang dikunjungi mempengaruhi jumlah spesies kupu-kupu yang ada di tiap wilayahnya.

\section{DAFTAR PUSTAKA}

Ariani L, Putu A, Liwa IHM. 2013. Keanekaragaman Dan Distribusi Jenis Kupu-Kupu (Lepidoptera) Di Kawasan Hutan Taman Wisata Alam Suranadi Sebagai Media Pembelajaran Biologi. Fakultas Keguruan dan Ilmu Pendidikan Universitas Mataram. Mataram.

Arisandi R \& Syamsi F. 2018. Keanekaragaman Jenis Kupu-kupu (Lepidoptera) di Taman Wisata Alam Muka Kuning Batam. SIMBIOSA 7(1):64-72.

Borror DJ, Triplehorn CA, Johnson NF. 1992. Pengenalan Pelajaran Serangga. Partosoedjono S, penerjemah: Brotowidjoyo MD: editor. Yogyakarta : Gadjah Mada University Press. Terjemahan dari: Ori an Introduction to the Study Of Insects.

Braby MF. 2004. The Complete Field Guide to Butterflies of Australia. Canberra: CSIRO Publishing.

BTNBT (Balai Taman Nasional Bukit Tiga Puluh). 2014. Rencana Pengelolaan Jangka Panjang Taman Nasional Bukit Tiga Puluh Periode 2015-2024. Pematang Rebah. Riau

Busnia M. 2006. Entomologi. Padang: Andalas University Press.

Campbel N A, Reece JB, Mitchell LG. 2000. Biologi. Jakarta: Erlangga.

Corbet AS \& HM. Pendlebury. 1992. The Butterflies of The Malay Peninsula. Oliver Boyd, Efdinburg and London.

Djarwaningsih T, Supriatna A, M. Amir. 2011. Flora Cagar Alam Gunung Tukung Gede Serang. Banten

Gusnenti AD. 2010. Penangkaran kupu-kupu Pachiliopta aristolochia (LEPIDOPTERA: PAPILIONIDAE) di Screen House dan Laboratorium [skripsi]. Bogor (ID): Institut Pertanian Bogor.

Herlina S. 2017. Kelimpahan Kupu-Kupu Nymphalidae di Kawasan Air Terjun Parangloe Kabupaten Gowa [Skripsi]. Makasar : Fakultas Sains Dan Teknologi, UIN Alauudin Makassar.

Jumar. 2000. Entomologi Pertanian. Jakarta: Penerbit Rineka Cipta.

Koh KP \& Sodhi NS. 2004. Importance Of Reverse, Fragments And Parks For Butterfly Conservation In A Tropical Urban Lanscape. Ecological Applications 14 (6): 16951708.

Mogan Y, Koneri R, Baideng EL. 2018. Keanekaragaman Kupu-kupu (Lepidoptera) di Kampus Universitas Sam Ratulangi, Manado. Jurnal Bioslogos 8(2): 60-67.

Nurjanah ST. 2010. Biologi Troides helena helena dan Troides helena hephaestus (Papilionidae) di penangkaran [Tesis]. Bogor (ID): Institut Pertanian Bogor.

Panjaitan, R. 2011. Komunitas Kupu-kupu Superfamili Papilionoidea (Lepidoptera) di Kawasan Hutan Wisata Alam Gunung Meja, Manokwari, Papua Barat. [Thesis] Intitute Pertanian Bogor. 
Peggie D, Amir M. 2006. Panduan Praktis Kupu-Kupu Di Kebun Raya Bogor. Cibinong: Pusat Penelitian Biologi-LIPI.

Peggie D. 2014. Mengenal Kupu-kupu. Jakarta: Pandu Aksara Publishing.

Plant of Southeast Asia. http://www.asianplant.net. [Mei 2019].

Putri RE, Mutiara D. 2014. Keanekaragaman Kupu-Kupu di Kecamatan Sukarame Kota Palembang Provinsi Sumatera Selatan. Sainmatika 11 (2):38-42.

Rahayu SE, Basukriadi A. 2012. Kelimpahan dan keanekaragaman spesies kupu-kupu (Lepidotera: Rhopalocera) pada berbagai tipe habitat di Hutan Kota Muhammad Sabki Kota Jambi. Biospecies 5(2): 40-48

Rinanda A, Farah D, Wahdina. 2016. Studi Keanekaragaman Jenis Kupu-Kupu di DAS Mendalam Taman Nasional Betung Kerihun Danau Sentarum Kabupaten Kapuas Hulu Provinsi Kalimantan Barat. Jurnal Hutan Lestari 4(4): 437-445

Rizal S. 2007. Populasi Kupu-kupu di Kawasan Cagar Alam Rimbo Panti dan Kawasan Wisata Lubuk Minturun Sumatera Barat. Mandiri 9 (3): 177-237.

Rueden CT et al. ImageJ2: ImageJ for the Next Generation of Scientific Image Data. BMC Bioinformatics DOI.10.1186/s128590171934z:18-529

Sari RP et al. 2019. Keanekaragaman kupu-kupu (insect: Lepidoptera) di Kebun Raya Purwodadi, Pasuruan, Jawa Timur, Indonesia. PROS SEM NAS MASY BIODIV INDON 5 (2): 172-178

Scobel MJ. 1995. The Lepidoptera: Form, Function and Adversity. New York: Oxford University Press.

Subahar TS, Yuliana A. 2012. Butterfly Diversity as a Data Base for the Development Plan of Butterfly Garden at Bosscha Observatory, Lembang, West Java. Biodiversitas 11 (1): 24-28.

Sulistyani TH. 2013. Keanekaragaman Jenis Kupu-Kupu (Lepidoptera: Rhopalocera) di Kawasan Cagar Alam Ulolanang Kecubung Kabupaten Batang [Skripsi]. Jurusan Biologi Fmipa UNS: Semarang.

The International Plants Names Index. 2011. http://www.ipni.org. [Mei 2019] The Plant List. 2013. http://www.theplantlist.org. [Mei 2019]

Triplehorn CA, Johnson NF. 2005. Borror and Delongs Introduction to The Study of Insect 7th Edition. United States Of America: Thomson Brooks/Cole. 